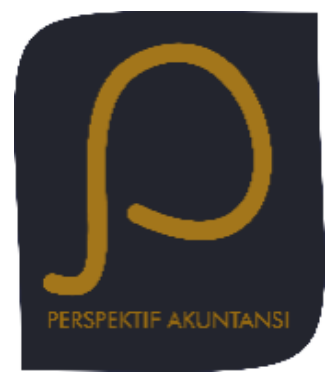

Perspektif Akuntansi

Volume 3 Nomor 2 (Juni 2020), hal. 167-177

ISSN: 2623-0194 (Print), 2623-0186 (Online) Copyright(C) The Authors(s). All Rights Reserved

Fakultas Ekonomika dan Bisnis,

Universitas Kristen Satya Wacana

DOI: https://doi.org/10.24246/persi.vXiX.p167-177

http://ejournal.uksw.edu/persi

\title{
Testing The Information System Success Models Through Myob Accounting Software
}

\author{
Septian Bayu Kristanto ${ }^{1}$ \\ Universitas Kristen Krida Wacana \\ Herni Kurniawati ${ }^{2}$ \\ Universitas Tarumanagara
}

\begin{abstract}
Received
$28 / 11 / 2019$

Abstract. The purpose of this study wants to test the Information System Succes Model through Accounting Software. The test

Accepted $28 / 06 / 2020$ examines the effect of System Quality to Service Quality, the effect of System Quality to Work performance, and the effect of Service Quality to Work Performance. The object in this research is MYOB accounting software. The data gathered with questionnaires in 2 types, paper, and online. From 500 questionnaires are distributed, 315 were returned. It consists of 194 respondents through online, and 116 respondents through the paper. The obtained data were analyzed using Structural Equation Modelling. The result of data analysis showed that the System Quality has a significant positive effect on the Service Quality, Service Quality has a significant positive effect on Work Performance, and System Quality have a significant positive effect on Work Performance. The overall result indicates that $M Y O B$ accounting software has good quality and related to user performance. Specifically, the user refers to the basic user, which is a university student.
\end{abstract}

\footnotetext{
${ }^{1}$ Email Korespondensi : septian.bayu@ukrida.ac.id

${ }^{2}$ Email : hernik@fe.untar.ac.id
} 
Keywords: IS Success Model, Service Quality, System Quality, Work Performance

\section{Introduction}

The rapid developments in information systems, greatly assist management in the decision-making process (Chang, Chen, \& Lan, 2012). The rapid development of information systems made the information system era as a gateway for corporate revival. Not only at the top level but also at the middle level and the lower level. One of the advantages of the information system era is the use of accounting programs as a tool for managers in decisions making. One of the top accounting software Minds Your Bussiness, well known as MYOB.

Some article shows MYOB is widely used in various levels of the company, even between countries. A dominant factor is the ease of use of this program. MYOB is a simple but complete program (Santamour, 2011). MYOB is one of the best accounting software used for company expansion and able to assist accountants in the internal audit process (Breen, Sciulli, \& Calvert, 2004). The ease of use is a strength of MYOB compared to other accounting software. This information is also supported that MYOB is one of the 5 accounting programs that are widely used by the middle to lower level companies (Hedtke, 2005). This survey, according to the convenience factor, the cheap price, and the provision of a trial version to helping consumers who will be testing the program.

The study about the success of information systems in company performance called the Information System Success Model (ISSM). This model was developed by DeLone and McLean (DeLone \& McLean, 1992), and revising their model, with an addition of new constructs, service quality (DeLone \& McLean, 2003).

This study aims to test the consistency of the DeLone and McLean models (DeLone \& McLean, 2003) regarding the success of information systems that have been running for a decade, and prove their impact on company performance. This research is a development of the previous studies in ISSM (Chang et al., 2012; Myers, Kappelman, \& Prybutok, 1997; Rai, Lang, \& Welker, 2002). The differences that occur in this study at the user level, where the success of the information system will be seen from student respondents, who are users with a basic level. The consistency of proof of this model will further strengthen the IS success model of DeLone and McLean for various levels of users, from basic to advance. 


\section{Theoretical And Hypotheses}

\section{Information System Success Model (IS Success Model)}

The Information System Success Model (ISSM) is a model of information systems theory that seeks a comprehensive understanding of success in identifying, describing, and explaining the relationships between dimensions in information systems (Chang et al., 2012). The initial development of this model was carried out by DeLone and McLean (DeLone \& McLean, 1992). This model was refined by the original author a decade later, by responding to feedback received from other researchers. Based on the theories and the results of previous studies that have been studied, DeLone and Mclean developed a parsimony model which they called the success model of the information system DeLone and Mclean (D\&M Success Model). This proposed model reflects the dependence of six measures of information system success (DeLone \& McLean, 2003). The six elements or factors or components or measurements of this model are System Quality, Use, User Satisfaction, Individual Impact, and Organizational Impact. This success model is based on the processes and causal relationships of the dimensions in the model. This model does not measure the six dimensions of measuring an information system's success independently but measures it as an overall one influencing the other. Process considerations argue that a system consists of several processes, namely, one process follows another process.

\section{System Quality and Service Quality}

The quality of the system is the overall quality of a system is also one of the most common dimensions along which evaluated information systems (Chang et al., 2012). The quality of the system indirectly impacts the extent to which the system can provide benefits through mediational relationships through the intention to use and construct user satisfaction. Along with information quality and system quality, information systems are also often evaluated according to the quality of service they can provide.

\section{Work Performance}

Accounting Information System Performance measures the effectiveness of accounting information systems using user satisfaction and system usage (Chang et al., 2012). The performance of accounting information systems dividing into two parts: user satisfaction and the use of information systems as a substitute for the performance of accounting information system variables. Information systems are widely used to demonstrate successful performance information system user satisfaction can be measured from certainty and what they need. When an information system is needed, the use of the system will 
decrease, and the success of management with the information system can determine user satisfaction (Chang et al., 2012).

\section{The relationship between system quality and service quality}

The dimensions of service quality construct measurement are divided into various aspects, such as tangibility, reliability, responsiveness, assurance, and empathy (Chang et al., 2012; Li, Tan, \& Xie, 2002). They suggest a factor in the technical expertise of personnel in the IT field and the provision of training to users to improve service quality. Other researchers, system quality, was divided system quality into four aspects: accessibility, usability, navigation, and interactivity. All aspects are proven to affect service quality (Keating, Rugimbana, \& Quazi, 2003). Based on the results of the testing of previous researchers, the first hypothesis $\left(\mathrm{H}_{1}\right)$ of this study can be formulated that system quality has a positive effect on service quality.

\section{The relationship between system quality and work performance}

System performance is divided into two constructs, namely, work performance and organizational commitment (Chang et al., 2012). Work performance refers to the results and achievements that can be obtained by each employee (individually) in their work. The success of these employees is caused by two factors: personal factors (knowledge, expertise, capabilities, motivation, attitude) and technical factors (interaction with superiors, encouragement, reward). Further, performance is related to how organizations achieve their goals (Tax, Colgate, \& Bowen, 2006). Both studies show that personal desires and commitments of organizations, support each other in achievements or even the reputation to be achieved. System quality is the measurement of the ability of information systems to handle errors, consistency of reporting, ease of use, and the output of documentation. Proving the quality of a sound information system will provide a simultaneous impact on user satisfaction and individual performance (DeLone \& McLean, 2003). This impact will have a direct influence on organizational performance. Based on the results of these researchers, it can be concluded the second hypothesis $\left(\mathrm{H}_{2}\right)$ in the study is the quality of information systems has a positive effect on work performance.

\section{The relationship between service quality and work performance}

The service quality concept means that reasonable organizational goals will give customers satisfaction in services so that multiple processes will occur (Chang et al., 2012; Rai et al., 2002). Multiple processes that occur here are a combination of quality service provided by an organization to customers, as well as the effect of the service that the customer responds to the organization. The concept of service quality is emphasized since information systems are 
widely used for the product marketing process. It pays special attention to service quality, where there is a gap between service expectations and service perceptions (Parasuraman, Zeithaml, \& Berry, 1988). This gap must be bridged by organizations employing communication (word of mouth), marketing experience, and customer needs surveys (Chang et al., 2012; Pitt, Watson, \& Kavan, 1995). With the results of other research (DeLone \& McLean, 2003; Myers et al., 1997) researcher proves that one of the success factors of an information system is service quality, then the third hypothesis $\left(\mathrm{H}_{3}\right)$ of this study was formulated that service quality has a positive effect on work performance.

\section{METHODS}

\section{Research types}

This research is quantitative research, which uses an instrument in the form of a questionnaire. The questionnaire was adopted from the previous study (Chang \& Chang, 2010) with the modification of omissions in the construct of job satisfaction. The respondents are students, which is assumed to have no sophisticated work experience with software that will be tested for quality and performance. The Respondents are bachelor students who have taken computer accounting courses using MYOB program. Before testing, the researchers take a pre-test the research questionnaire for employee class students and final year students who had also used the MYOB program. The MYOB program was chosen in this study because it is widely used in Higher Education in Indonesia, and is widely used by middle and upper-level companies. The sample collection technique is done by using a convenience sampling method.

\section{Research model}

Based on the hypothesis made in this study $\left(\mathrm{H}_{1}, \mathrm{H}_{2}\right.$, and $\left.\mathrm{H}_{3}\right)$, researchers can design a research model like figure 1 below. The construct used in this study consists of system quality, service quality, and work performance. The system quality construct is divided into three dimensions: security (3 indicators), ease of use ( 3 indicators), and efficiency ( 4 indicators). The service quality construct is divided into two dimensions of reliability (4 indicators) and responsiveness (4 indicators). Work performance consists of five indicators. 


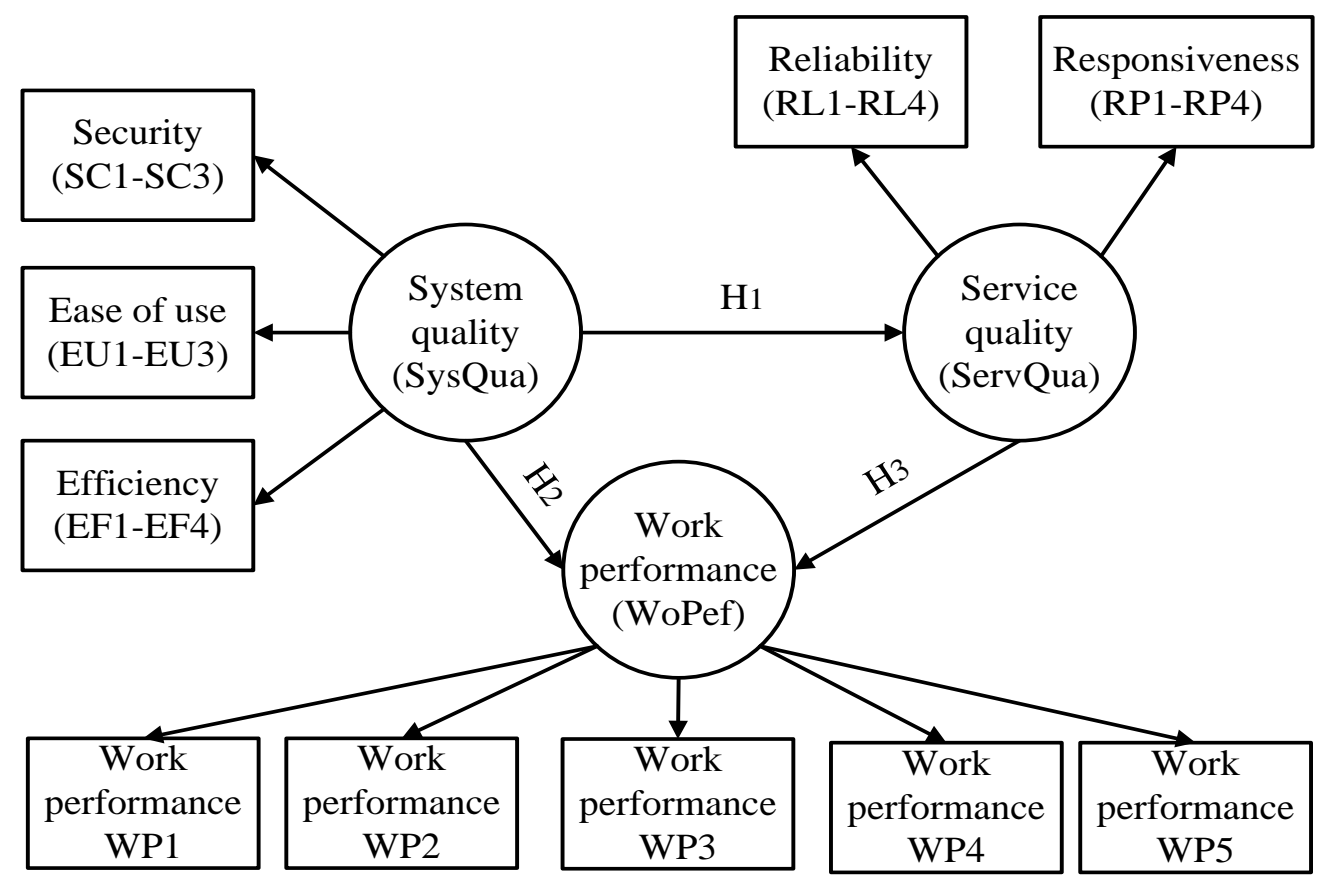

Figure 1. Research Model

Latent variables in the study consist of three variable: system quality (SysQua), service quality (ServQua), and work performance (WorkPef). The observed variables of this study were divided into six dimensions. To measure SysQua, there are three dimensions: security (SC1, SC2, SC3), ease of use (EU1, EU2, EU3), and efficiency (EF1, EF2, EF3, EF4). To measure ServQua, there are two dimensions: reliability (RL1, RL2, RL3, RL4) and responsiveness (RP1, RP2, RP3, RP4). While the WorkPef measurement comes from the dimensions of work performance (WP1, WP2, WP3, WP4, WP5), all variables observed in this study were measured on a 4 Likert scale, consisting of levels of strongly disagree, disagree, agree, and strongly agree. The use of a Likert scale four is done by researchers to avoid bias in the results of neutral answers. Besides, researchers can also see the tendency of respondents' answers if the answer options are divided on an even scale.

\section{Data analysis method}

Model testing is done by Structural Equation Model (SEM) analysis procedure. SEM analysis consists of 3 parts: overall model fit test, measurement model fit test, and structural model fit test (Kline, 2012). The overall model fit test is performed with the results of the output goodness of fit results. The criteria are Root Mean Square Error of Approximation (RMSEA), Expected Cross Validation Index (ECVI), Akaike Information Criterion (AIC), Consistent Akaike Information Criterion (CAIC), Normed Fit Index (NFI), Non Normed Fit Index 
(NNFI), Comparative Fit Index (CFI), Incremental Fit Index (IFI), Relative Fit Index (RFI), and Goodness of Fit Index (GFI). The measurement model fit test is performed using Construct Reliability (CR) and Variance Extracted (VE). The standard for validity and reliability is over 0.7 for CR and 0.5 for VE (Kline, 2012). The last one is the structural model fit test. This test is to ensure the direction and significance of the relationship between latent variables in the study.

\section{RESULTS AND DISCUSSION}

\section{Demographics of Respondents}

The researcher distributes 500 questionnaires among students, and 310 of them were returned. From the total questionnaires distributed, we have a $62 \%$ response rate. The questionnaire returned comes from online (google form) are 194 students, and from the physical form are 116 students. For the final sample questionnaires, the researcher eliminates 45 questionnaires that having a homogenous filling, the same answer for all questions. So the final questionnaire used is 265 data. The final research data filed $67 \%$ by female, and $33 \%$ by the male. The study found that 55 students are freshmen, 93 students are sophomore, 117 students are seniors, and they are coming from 8 universities in Jakarta. The respondents consist of $35 \%$ of students with working experience, and 29 of them use MYOB in daily activities.

\section{The overall fit model result}

The overall test result is reflected in the Goodness of fit statistics (Kline, 2012). According to the following table, the overall result shows that the research model is a good fit condition.

Table 1. The overall fit model result

\begin{tabular}{|c|c|c|}
\hline Criteria(s) & Result & Conclusion \\
\hline RMSEA & 0.043 & Good fit \\
\hline ECVI & $\begin{array}{c}\text { Model }=1.55 \\
\text { Saturated }=1.92 \\
\text { Independence }=20.88\end{array}$ & Good fit \\
\hline AIC & $\begin{array}{c}\text { Model }=408.60 \\
\text { Saturated }=506.00 \\
\text { Independence }=5512.16\end{array}$ & Good fit \\
\hline
\end{tabular}




$\begin{array}{ccc}\text { CAIC } & \begin{array}{c}\text { Model }=701.70 \\ \text { Saturated }=1664.67 \\ \text { Independence }=5612.91\end{array} & \text { Good fit } \\ \text { NFI } & 0.95 & \text { Good fit } \\ \text { NNFI } & 0.98 & \text { Good fit } \\ \text { CFI } & 0.98 & \text { Good fit } \\ \text { IFI } & 0.98 & \text { Good fit } \\ \text { RFI } & 0.94 & \text { Good fit } \\ \text { GFI } & 0.91 & \text { Good fit }\end{array}$

\section{The measurement fit model result}

The measurement fit model evaluates the validity and reliability of the latent variable. The standard score is 0.7 for CR and 0.5 for VE (Kline, 2012). The following table prove that System Quality (SysQua), Service Quality (ServQua), and Work Performance (WorkPef) are valid and reliable

Table 2. The measurement fit result

\begin{tabular}{ccc}
\hline Latent variable & CR & VE \\
\hline SysQua & 0.7701 & 0.5162 \\
ServQua & 0.7715 & 0.5380 \\
WorkPef & 0.7219 & 0.5865 \\
\hline
\end{tabular}

\section{The Structural fit model result}

The structural model represents the magnitude effect for latent variables. From the figure 2, the research model confirms that System Quality (SysQua) positively significant to Service Quality (ServQua), and Service Quality (ServQua) positively significant to Work Performance (WorkPef). Another finding is the association between System Quality (SysQua) to Work Performance (WorkPef) is not significant. 


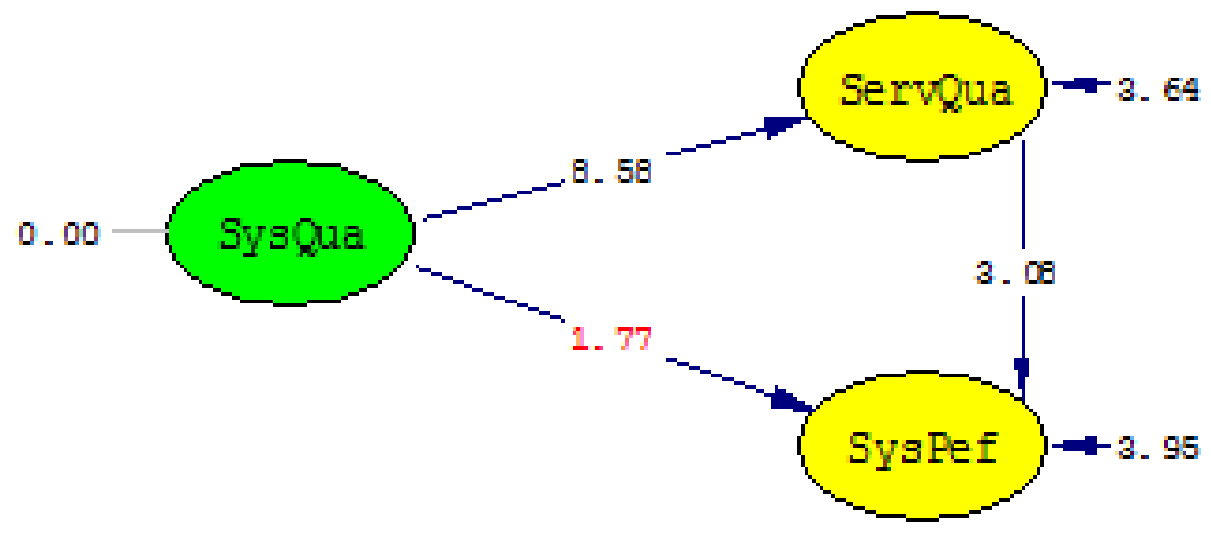

Figure 2. Path Diagram of Structural Model

\section{Discussion}

This study aims to examine the effect of System Quality (SysQua) on Service Quality (ServQua) on the MYOB application, to test the effect of System Quality (SysQua) on Work Performance (WorkPef) on the MYOB application, and to test Service Quality (ServQua) on Work Performance (WorkPef) against the MYOB application. The structural model fit test results show that the first hypothesis is proven that System Quality (SysQua) has a positive effect on Service Quality (ServQua). This means that if System Quality (SysQua) is level, it can improve Service Quality (ServQua) on the MYOB application. With the proof of this hypothesis, this research is in line with previous researchers (Chang et al., 2012; DeLone \& McLean, 1992; Keating et al., 2003; McKinney, Yoon, \& Zahedi, 2002).

Furthermore, it is also proven in the second hypothesis that System Quality (SysQua) has a positive effect on Work Performance (WorkPef). It means that if the System Quality (SysQua) is graded it will affect the Work Performance (WorkPef) of the MYOB application. The results of this study are in line with previous research (Chang et al., 2012; DeLone \& McLean, 2003; Tax et al., 2006). In the last hypothesis, it is proven that Service Quality (ServQua) has a positive effect on Work Performance (WorkPef). Accordingly, if Service Quality (ServQua) is level, it can affect Work Performance (WorkPef) on the MYOB application. The results of this study are also in line with the previous researcher (Chang et al., 2012; DeLone \& McLean, 2003; Myers et al., 1997; Pitt et al., 1995; Rai et al., 2002). 


\section{CONCLUSION}

This study aims to examine the effect of System Quality (SysQua) on Service Quality (ServQua) on the MYOB application, to test the effect of System Quality (SysQua) on System Performance (SysPef) on the MYOB application, and to test Service Quality (ServQua) on System Performance (SysPef) against the MYOB application. The structural model fit test results (Structural Model Fit ) show that the first hypothesis is proven that System Quality (SysQua) has a positive effect on Service Quality (ServQua). This means that if System Quality (SysQua) is level, it can improve Service Quality (ServQua) on the MYOB application. Furthermore, it is also proven in the second hypothesis that System Quality (SysQua) has a positive effect on System Performance (SysPef). This means that if System Quality (SysQua) is level, it will affect System Performance (SysPef) in the MYOB application. In the last hypothesis, it is proven that Service Quality (ServQua) has a significant positive effect on System Performance (SysPef). This means that if Service Quality (ServQua) is level, it can affect System Performance (SysPef) in the MYOB application.

In this study, there are limitations; namely, some universities do not have MYOB courses. Therefore, researchers provide some suggestions for further researchers who want to continue this research: (1) In this study, researchers only examined MYOB software. Researchers can then examine other software, such as Accurate, Quick Book, Zahir, Peach Tree, Office Accounting. (2) The researcher further hopes to distinguish users who use MYOB for less than one year and more than one year. And (3) researchers can further distinguish the MYOB use, which is daily or rare.

\section{REFERENCES}

Breen, J., Sciulli, N., \& Calvert, C. (2004). The Role of the External Accountant in Small Firms. Small Enterprise Research. https://doi.org/10.5172/ser.12.1.5

Chang, C. S., \& Chang, H. C. (2010). Moderating effect of nurses' customer-oriented perception between organizational citizenship behaviors and satisfaction. Western Journal of Nursing Research. https://doi.org/10.1177/0193945909355995

Chang, C. S., Chen, S. Y., \& Lan, Y. T. (2012). Motivating medical information system performance by system quality, service quality, and job satisfaction for evidence-based practice. BMC Medical Informatics and Decision Making https://doi.org/10.1186/1472-6947-12-135

DeLone, W. H., \& McLean, E. R. (1992). Information System Success- the Quest for the Dependent Variable.pdf. Information Systems Research

DeLone, W. H., \& McLean, E. R. (2003). The DeLone and McLean model of information systems success: A ten-year update. In Journal of Management Information Systems. https://doi.org/10.1080/07421222.2003.11045748 
Hedtke, J. (2005). Small Biz Software Gets Bigger. Accounting Technology.

Keating, B., Rugimbana, R., \& Quazi, A. (2003). Differentiating between service quality and relationship quality in cyberspace. Managing Service Quality: An International Journal. https://doi.org/10.1108/09604520310476481

Kline, R. (2012). Assumptions in structural equation modelling. In Handbook of Structural Equation Modeling.

Li, Y. N., Tan, K. C., \& Xie, M. (2002). Measuring web-based service quality. Total Quality Management. https://doi.org/10.1080/0954412022000002072

McKinney, V., Yoon, K., \& Zahedi, F. (2002). The measurement of Web-customer satisfaction: An expectation and disconfirmation approach. Information Systems Research. https://doi.org/10.1287/isre.13.3.296.76

Myers, B. L., Kappelman, L. A., \& Prybutok, V. R. (1997). A Comprehensive Model for Assessing the Quality and Productivity of the Information Systems Function: Toward a Theory for Information Systems Assessment. Information Resources Management Journal (IRMJ). https://doi.org/10.4018/irmj.1997010101

Parasuraman, A. ;, Zeithaml, V. A. ;, \& Berry, L. L. (1988). Servqual: A Multiple-Item Scale For Measuring Consumer Perc. Journal of Retailing; Spring.

Pitt, L. F., Watson, R. T., \& Kavan, C. B. (1995). Service quality: A measure of information systems effectiveness. MIS Quarterly: Management Information Systems.

Rai, A., Lang, S. S., \& Welker, R. B. (2002). Assessing the validity of IS success models: An empirical test and theoretical analysis. Information Systems Research. https://doi.org/10.1287/isre.13.1.50.96

Santamour, B. (2011). MYOB? It's still good advice. Hospitals and Health Networks.

Tax, S. S., Colgate, M., \& Bowen, D. E. (2006). How to prevent your customers from failing. MIT Sloan Management Review. 